\title{
Participation as pedagogy: Student and librarian experiences of an Open Access publishing assignment
}

Alison Hicks, Swedish School of Library and Information Science, University of Borås/

Department of Information Studies, UCL. Email: alison.hicks@hb.se

\begin{abstract}
Education for Instruction Librarians has traditionally centered upon the acquisition of practical classroom skills. While this approach has merit, from a sociocultural perspective of learning, student development emerges more completely through engagement with the communal activities and values that constitute professional practices rather than through the achievement of individual competencies. Drawing upon these understandings, this paper reports on the experiences of an Open Access writing assignment that was librarian-reviewed. The assignment was designed to build student participation within Instruction Librarian practices and communities. Focused upon the 19 student and 19 librarian-reviewer experiences (38 total) of the assignment, the survey-based methodology that is used in this study reveals a lack of

communication between student and practitioner Instruction Librarians as well as the importance of the assignment to both student and librarian learning. These findings demonstrate that developing student access to professional practices and communities can be beneficial for students as well as for Instruction Librarians.
\end{abstract}

Keywords: Information Literacy, Transition, Library Instruction, Teaching Methods, Student Publishing

\section{Introduction}

How do we approach the education of future Instruction Librarians? The prominence of user education within Library and Information Science (LIS) means that students, librarians and faculty are interested in developing effective ways to prepare learners for teaching librarian positions. Traditionally, the need for proficient teachers has centered Instruction Librarian education upon the practical classroom skills that students are seen to be lacking, such as the ability to present instructional content. From a sociocultural perspective, however, these ideas are incomplete because they neglect to account for the "networks, connections, and actions that exist among people working in consort" (Lloyd, 2007, p.183), or the idea that knowledge and learning emerges with and between other professionals in the field. Recognizing the need to design learning opportunities that facilitate this community engagement, this paper reports on an LIS assignment that was restructured through a sociocultural lens as a librarian reviewed chapter in an Open Access book. Insights from this study will facilitate reflection on the role of professional communities within LIS education, as well as the mechanics of facilitating these connections within Instruction Librarian education and beyond.

Using a survey-based methodology, the 38 participants in this pedagogical experiment (19 students and 19 reviewers) were asked to reflect upon their experiences of the assignment in order to evaluate its use and effectiveness. Focused upon student and reviewer reactions, analysis aimed to explore both the value and the worth of the assignment to individual students and to the development of Instruction Librarian communities. The paper will start by providing an overview of the theory that informed the design of this assignment before reviewing literature that explores the training and education of new Instruction Librarians as well as studies related to 
student publishing. It will then report on the findings from two open-ended questionnaires that explored student and librarian-reviewer reactions to and experiences of the assignment. The paper will finish by outlining recommendations for future implementations of the assignment as well as directions for further research.

\section{Context}

The impetus and motivation for this assignment builds on sociocultural ideas of development and transfer. Grounded in the work of Vygotsky (1978), sociocultural theories are constructed upon the idea that dialog forms the basis for the organization of social reality (Limberg, Sundin \& Talja, 2012). Centering attention on the complex and ongoing formation of meaning, these understandings establish knowledge as situated, or connected to a specific practice (Limberg et al., 2012) and as social, or realized through and in relation to a community's negotiated practices. The importance that is placed upon the idea of social context further re-situates learning at the heart of the community, or upon the notion of interaction and the sharing of group cultures (Rogoff, 2003). Within the field of LIS, and drawing upon Lave and Wenger's 1991 work into situated learning, the shift from the individual to the social repositions Instruction Librarians as forming part of loose and informal occupational communities who share common vocabularies, tools and activities as well as more tacit ways of thinking about and critiquing these understandings. Defined as "an aggregate of people who come together around some enterprise" (Eckert \& Wenger, 1994), the community of practice concept has been explored within information research as the site of both student learning (Harris, 2008) as well as newcomer workplace information practices (Moring, 2012). Within this study, however, the concept of Instruction Librarian communities is used to provide a useful analytical framework "for thinking about learning in its social dimensions" (Wenger, 2010, p.179), rather than as a presumed autonomous and bounded entity. In this sense, these ideas highlight that it is through the ongoing negotiation of shared histories and activities that teaching librarian experience is produced and competence is developed (Wenger, 1998).

These understandings had several important implications for the design of this project. Firstly, the recognition that student learning is driven by participation within a group's activities and practices meant that the assignment would have to be designed around a typical or common practice in the field. Given librarian interest in sharing best practices as well as in teacher professional development, a writing project that focused on synthesizing current literature on a topic would accurately reproduce the writing and publishing in which many librarians engage. Most importantly, however, the emphasis on situated and negotiated knowledge created a need to integrate students into the heart of ongoing meaning-making, or to help them learn from and through the community's activities, rather than just about it. Embodying the values and the ways of knowing of individuals who already "occupy a position in a professional discourse" (Drabinski, 2016, p. 34), peer-review with experts in the field was seen to form an ideal way to for students to glimpse the values and the meaning that structure understanding within Instruction Librarian communities and practices. As Lloyd points out, it is this type of contingent and nuanced knowing that is hard to make visible, yet so vital to the development of competence in the workplace (2014).

At the same time, an assignment that was uniquely focused on the reproduction of librarian practices ran the risk of implying that newcomers have little to contribute to a community and that knowledge and groups are static and unchanging. These ideas were further complicated by the complexity of modern information landscapes, which make it impossible to 
predict what challenges new professionals may encounter and, in fact, whether experts actually possess the knowledge that novices may need in the future (Tuomi-Grohn, 2003). In other words, an assignment that was uniquely focused upon a unidirectional transfer of knowledge from practitioner to student or from novice to expert could be seen to idealize the professional community, or to obscure ideas of criticism and change. These ideas meant that the assignment would also have to be designed around students' active interpretation and reconstruction of knowledge practices rather than their passive assimilation of professional knowing.

A recognition of these needs led to the idea of a collaborative project of mutual interest where workplace and school can learn from each other (Konkola, Tuomi-Grohn, Lambert \& Ludvigsen, 2007). More concretely, these ideas meant that the assignment would have to be structured around a broader consideration of what students could bring to this assignment that Instruction Librarians could not. Although students may not yet have as much practical teaching experience, their enrolment in this class meant that, unlike many practicing Instruction Librarians, they did possess the time to reflect on and explore instruction issues in detail. They also had the benefit of fresh eyes and a wealth of experience from other fields. Matching these students' advantages of time with the librarians' need to keep up, a writing assignment that was designed for professionals in the field could be understood as constituting a mutually beneficial activity in which students were actively negotiating, contributing to and participating within established community practices and activities, rather than merely processing its knowledge.

\section{Literature Review}

Having explored the background for this project, the paper will now turn to reviewing relevant literature related to library instruction education and student publishing opportunities.

\section{Training of Instruction Librarians}

Literature that explores the education of Instruction Librarians starts in the early 2000s and focuses, for the most part, on librarian designed in-house instructional training programs as libraries and LIS programs alike struggled to keep up with renewed interest in teaching (Botts \& Emmons, 2002). By the mid 2000s, however, library schools had caught up with demand, and research reported that the number of LIS programs in the United States (U.S.) that offered an instruction course grew from 26/48 in 1999 (Westbrook, 1999) to 46/54 in 2008 (Sproles, Johnson \& Farison, 2008). In the interim, U.S. professional associations had become far more involved with the training of librarians, too, with the Association of College and Research Libraries (ACRL) Immersion program starting in 1999, the ACRL Instruction Section Proficiencies for Instruction Librarians taskforce being convened in 2004 (Westbrock \& Fabian, 2010) and the New York-based Library Instruction Leadership Academy emerging in 2010 (Davies-Hoffman, Alvarez, Costello \& Emerson, 2013). As a whole, however, and despite the fact that in-house training was often valued in the U.S. for its focus on peer learning (Cooke \& Hensley, 2013; Walter, 2008), most studies of Instruction Librarian education to date have focused almost exclusively on the individual competencies or the proficiencies that are seen to be necessary for the formation of Instruction Librarians, as the South African based Selematsela and Du Toit (2006) point out, among others (Shonrock \& Mulder, 1993; Westbrock \& Fabian, 2010). In effect, while studies from the United Kingdom (U.K.) (Bewick \& Corrall, 2010; Inskip, 2015) and the U.S. (Hensley, 2015) show that students and new librarians alike are keen to increase instruction education within LIS programs, it is clear that most of these educational opportunities center on the "design, delivery, and assessment of instruction" (Saunders, 2015, p.16), rather 
than on an exploration of new professional identities and roles. An exception can be found in the work of U.S.-based Cooke and Hensley (2013), who acknowledge the need for librarians to develop their own teaching voice.

More recent studies of library instruction syllabi point to increased interest in and engagement with experiential education within the field of LIS, including a drive to facilitate student participation within teaching communities in both the U.S. (Hensley, 2015; Saunders, 2015) and in Canada (Ishimura \& Bartlett, 2009). While the majority of U.S.-focused experiential learning initiatives within LIS have centered upon culminating practicum, internships and service learning opportunities (see Cooper, 2013 for a review), Saunders (2015) and Hensley (2015) report that library instruction courses are starting to incorporate authentic and active learning opportunities into the curriculum, including leading instruction sessions in a public library. Ishimura and Bartlett report similar findings in their 2009 U.S./Canadian study, although it seems that these initiatives tend to be directed at the LIS instructor rather than at reallife students. A more specific example of an authentic learning opportunity can be found in Cooke and Hensley (2013) and Hensley (2015) where students who were enrolled in an advanced library instruction course in the U.S. taught a series of workshops to graduate students in other disciplines. As Hensley (2015) points out, these opportunities provided an important opportunity for students to practice their teaching in a way that mirrors actual classroom conditions. At the same time, and although these assignments offered unique opportunities to engage with learners as a teacher, Hensley's 2015 research demonstrates that few library instruction courses seem to facilitate interaction with other teacher-librarians beyond occasionally asking students to follow an Instruction Librarian listserve or Twitter chat. While recognizing that mentoring relationships with professionals in the field may be as hard to facilitate as to maintain, it is clear that from a sociocultural perspective, the isolation of students from teacher-librarians can be seen to impede intersubjective learning and growth.

In summary, while the literature demonstrates that early librarian education often emerged from and was situated within teaching librarian communities, learning almost exclusively focused on individual and highly practical proficiencies and competencies. In contrast, later studies demonstrate that library instruction education within Canada, the U.S. and the U.K. is now frequently integrated into the LIS curriculum and incorporates substantial theoretical background as well as authentic assignments into coursework. In becoming more institutionalized, however, teaching librarian education now often occurs at a considerable distance from teaching librarian communities and practices, which has a corresponding effect on student engagement with their teaching role, identity and sense of belonging. As Walter points out, "professional skills and professional identity... are complementary aspects of a holistic approach to teacher education" and it is important to recognize and address both aspects in the design of Instruction Librarian education (2008, p. 55).

\section{Publishing as Pedagogy}

One way in which educators have worked to break down barriers between novices and experts within a field is through student publishing. Open Access publishing more generally has been credited with opening up and broadening the scope of scholarly publishing by exposing who gets to control the meaning, flow, and accessibility of information (Miller, 2013). Yet, as Miller goes on to point out, the focus on merely making research available, rather than questioning what constitutes legitimate knowledge, or who gets to contribute, is "no less inimical than [the system] which it purports to disrupt" (2013, p. 4). In other words, a failure to acknowledge how 
established scholarly models often privilege certain academic or faculty voices risks undermining the very premise and promise of open access publishing. Seen in this light, student publishing, which emerges from a growing interest in high impact practices and undergraduate inquiry-based learning (Caprio, 2014), not only provides a way to complete the cycle of research, but importantly, also enables students to participate in and integrate into the academic conversation that characterizes and structures their surrounding communities. After all, if we believe that students have nothing to contribute to a field, then "it is worth asking ourselves what such an attitude communicates to students about the nature of the ... discipline and their place within it" (Hicks \& Howkins, 2015, p. 355).

Typically explored from an undergraduate level, student publishing can nonetheless be seen as especially relevant to libraries due to the prevalence of tenure-track positions. Beyond these expectations, however, it is clear that the presence of an audience, reviewer comments (Stone, Jensen \& Beech, 2016; Walkington, 2012) and the revision process that is often built into research opportunities when there are higher levels of public scrutiny, is highly beneficial for writing (Walkington, 2012). Students also report that their publishing experiences have led to career opportunities (Alexander, Colman, Kahn, Peters, Watkinson \& Welzenbach, 2016; Walkington, 2012). Most importantly, however, several U.K. and U.S. studies have found that through being "recognized as researchers in their own right... [students] begin to develop a sense of belonging to the research community" (Walkington, 2012, p. 558). In other words, writing and publishing opportunities not only facilitate a broader understanding of and contact with the research communities that surround these students but they also enable authentic participation in the practices of the field. This enables students to write their way into, rather than from, a position of expertise (Sommers \& Saltz, 2004) or to develop their own sense of belonging and voice in the field. As one student in Sommers and Saltz's U.S. based study puts it, "If I hadn't written, I would have felt as if I was just being fed a lot of information. My papers are my opportunity to think and say something for myself" (2004, p. 128).

As could be expected, several authors acknowledge that there are challenges associated with this type of assignment. Although Stone, Jensen and Beech were working with an undergraduate research journal, they found that they had to provide considerable detailed guidance for many students, including "writing an abstract, what to add in an acknowledgement section, the format of figures and copyright of images" (2016, p. 162). With hindsight, they recommend better communication of expectations and the provision of writing workshops. Similarly, Walkington (2012) found that being able to talk through reviewer comments rather than just receiving a list of changes would have been more beneficial for her students, most of whom were unaccustomed to receiving this type of constructive criticism on their work. Other authors are generally resistant to this type of assignment, believing that student research is either too immature or too unpolished for publication (Miller, 2013). However, as Walkington and Jenkins (2008) point out, the idea of a publication opportunity need not be limited to traditional journal articles; in fact, one of the benefits of these publishing assignments is that they start to "widen... the 'intellectual spaces' in which... research publication can be valued." On the whole, though, most authors indicate that student publishing forms a positive, if occasionally a timeconsuming experience, both for students and for faculty.

\section{Methodology and Methods}

Having explored the background for this study, the paper will now turn to providing an overview of the assignment and the research methods that will be used in this study. 


\section{Assignment}

This study centers on the experiences of a writing assignment for LIS 4330: Library Instruction, an elective class in the LIS program at the University of Denver. Within this class, which is the only one in the program that is dedicated to library instruction, students develop their understanding and knowledge of teaching and learning practices through a variety of practical, theoretical and reflective activities. This broad scope, as well as the short ten-week semester, mean that any assignments have to be flexible and meaningful enough to meet a wide range of student backgrounds, experiences and professional goals.

Building upon these practical constraints as well as literature from the field, the class instructor introduced the possibility of an open access and librarian-reviewed paper on the first day of class. While the instructor had long been committed to the value of student publishing it was important to her that students in the class felt comfortable with the idea, especially given the relative visibility and permanence of their future work. Initial reactions, however, were positive and the students became enthusiastic at the idea of a tangible product for their Curriculum Vitae (CV). Importantly, students also indicated that they were excited at the opportunity to work with "real" librarians. Although a couple of individuals had prior experience teaching in a public school system or were employed as a graduate teaching assistant, it became clear that most members of the class had very limited engagement with practicing librarians.

Having finalized details of the assignment with the class, the official brief called for a 3000-word paper on a topic that was related to instruction and that would be useful for a busy Instruction Librarian. The paper was then double-blind reviewed by an expert in the field before the final draft was published as part of a class book and archived in the University of Denver's institutional repository. Covering any instruction, education or information literacy topic in which students were interested, and taking the shape of either an essay or an annotated bibliography, the scope of the assignment was flexible enough to incorporate students' varying concerns and experiences.

Taking place over a six-week period, the class project integrated a number of check-in points to help scaffold the assignment and provide formative feedback to students before the paper was graded at the end of the quarter (see Table 1 for the schedule). The first step of the project centered on topic selection, which provided an early opportunity for the instructor to provide guidance on the suitability of the proposed paper. This stage also gave the instructor enough information to begin to match reviewers with student papers, a process which took place during the following ten days. Based, for the most part, on the instructor's professional contacts as well as knowledge of the surrounding Colorado and Wyoming librarian communities, the variety of student topics meant that the instructor also had to 'cold-call' individuals that she did not personally know in order to find a suitable reviewer. Beyond possessing expertise in a specific area, reviewers also had to be able to provide feedback on student work during a specific one-week window, given the short time frame of the quarter.

\section{Week Student Deadline Instructor Deadline}

\begin{tabular}{|c|c|c|}
\hline Week 4 & Submit topic & Provide feedback on topic. Meet students as needed. \\
\hline Week 5 & & Contact potential reviewers based upon student topics \\
\hline
\end{tabular}




\begin{tabular}{lll}
\hline Week 7 & First draft due & Send drafts to reviewers \\
Week 8 & Receive feedback & Provide feedback and compile reviewer comments \\
Week 10 & Second draft due & Grade papers \\
\hline
\end{tabular}

Table 1: Assignment schedule

Students submitted the first draft of their paper in Week 7. After ensuring that student work was anonymized in accordance with the double-blind review structure of the assignment, the instructor sent each paper to its reviewer along with reviewing guidelines and instructions. Recognizing that many individuals who agreed to participate in this project also review for professional journals, the instructor reminded the reviewer of the purpose of the assignment, as well as the need to provide constructive criticism of what often amounted to a novice librarian's first foray into the world of professional librarianship. The instructor also reviewed each paper herself, providing substantial feedback on readability, format and content. Upon receiving reviewer comments, the instructor skim read and anonymized feedback before passing this advice and suggestions along to the students. Students were then given two weeks in which to make any corrections or changes before the final draft was graded at the end of Week 10. After final assessment, papers were compiled into a book and uploaded to the University of Denver's institutional repository. A final step involved promotion of the book amongst the librarian communities for which it was designed through social media and professional listserves.

\section{Methods}

Student and practitioner interest, as well as the number of potential issues that could have affected this assignment (such as student discomfort or reviewer fatigue) led the instructor to explore the nature of the assignment in greater detail. To this end, the research questions for this paper can be summarized as:

1. How do students and reviewers experience participation in an open access publishing assignment?

2. How does participation in this project affect the development of Instruction Librarians identities?

Employing a descriptive survey method, two separate open-ended questionnaires (see Appendix A) were employed to capture student and reviewer experiences of the open access publishing assignment (Pickard 2007). More specifically, the student questionnaire focused on students' experiences of the assignment in relation to its value for their future program, career and library instruction goals. In contrast, the reviewer questionnaire centered on the reviewing experience and the perceived value of the assignment for Instruction Librarian communities. Administered after the reviewers had turned in their feedback and students had handed in their final paper, each questionnaire was anonymous and no identifying data was collected. The need to collect data before the end of the school year meant that the instructor also ensured that students were given the option of withholding their consent to participate in the research, firstly through a consent form that was attached to the questionnaire and secondly, through the instructor's collection of completed answers in an unobserved location. Due to distance, reviewer questionnaires were carried out online. Data analysis was carried out after final grades were entered. Nominal data 
from questionnaire answers was coded into categories or broad themes using an emergent coding process, where codes emerged from a close reading of student and reviewer answers.

\section{Participants}

Eighteen out of 19 students who were enrolled in LIS 4330 during Winter Quarter 2016 took part in this research. While individual demographics were not collected, students represented a mix of first and second year students, as well as students with and without prior teaching experience. All 19 reviewers participated in the survey of their experiences. Recruited through the instructor's professional contacts, reviewers were drawn from five states within the U.S., as well as from Canada and the U.K.. Reviewers were all involved in information literacy teaching and research, and comprised a mix of tenured, tenure track and non-tenure track academic librarians as well as public librarians, school librarians and LIS researchers.

\section{Findings}

The paper will now turn to explore findings from the questionnaires (see Appendix A) that were administered to the students and the reviewers who participated in this project, including their experience of the peer review process, as well as the effect of the assignment on Instruction Librarian development.

\section{Peer Review Process}

Student experiences. Overall, students commented highly favorably on the peer review process, finding that the experience was useful for broadening and for providing valuable validation of their work. In terms of their writing, reviewer comments were variously described by students as being "useful," "spot on" and helping to strengthen their paper. Underlining where points needed clarification or appeared to be unsubstantiated or overblown, reviewer comments were also valued for their suggestions about further reading, including sources that students may not have known about. Most importantly, several students remarked that they found the general peer review experience highly validating, with one student commenting "I enjoyed the idea that a real librarian deemed my writing worthy." The experience and subsequent boost to their confidence process was also seen as a useful transitional moment, being labeled by one student as "a helpful, valuable experience prior to entering the "real world."”

Naturally, experiences were not always uniformly positive, and two students found that a perceived mismatch between their paper topic and their reviewer's expertise affected the quality of their comments. Students also hinted at the unease they had faced when submitting their work, with students commenting that the experience "was TERRIFYING!" (sic), albeit "less painful" than they expected. At the same time, students appreciated that the reviewers recognized these fears with one student remarking that their reviewer "had some great feedback and suggestions for the things I could add to my paper without being too negative in their comments." The double blind structure of the review was also seen to help minimize student fears. In effect, while students were sensible of the extra pressure that this assignment brought, it was also seen to be beneficial, with one student stating that this "made me want to polish it [the paper] more than I would for other classes."

Reviewer experiences. Like the students, reviewers agreed that participation in this project was highly positive. Noting that they often learned from these papers, reviewers also commented favorably on choices of topic, especially when it was on a theme that they perceived had been overlooked within professional literature. They were often pleased at the quality of the 
paper that they were asked to look over, with one reviewer commenting "if anything, I was surprised that the paper was already in such good shape when I received it as the student exhibited a strong understanding prior to review." Reviewers also indicated that this assignment would provide a useful product for its librarian audience, noting "that there aren't a lot of 'trade' publications for librarians to give them quick information on a topic." Lastly, reviewers applauded students for submitting their work to peer review, positioning it as a useful (if intimidating) process to experience before they enter the less sheltered professional sphere because "it forces them to leave their comfort zone and expose their own work to the big, scary world."

At the same time, reviewers noted a number of consistent issues that emerged from their experience of reviewing student papers. One of the major problems relates to the students' lack of practical experience; as one reviewer put it, "students are tackling real-world issues and sometimes not with real-world experience." The lack of experience translated into the inclusion of "sweeping general statements" (although the reviewer indicated that they likely did the same when they were a student), as well as "unexamined assumptions" and a failure to include what reviewers perceived as core articles or resources in the field. Other reviewers found that the focus on scholarly literature rather than on practical examples made the topic less useful than expected. Reviewers also pointed out the dangers of oversimplification, both in terms of complexity, or "trying to summarize something too neatly in order to meet the space and pagelength requirements" as well as in terms of nuance; in attempting to establish their opinions or claims, reviewers pointed out that students seemed to criticize rather than encourage the reader, or fail to respect "diverse readers and the experience that they may bring to reading an article." Reviewers were also aware that the feedback they were giving may have been more encouraging than is normally provided during peer review, which may "set students up for unrealistic expectations and later frustration."

\section{Effects on Learning and Development}

Student experiences. In contrast, responses to questions about the effect of this project on the development of Instruction Librarian identity and understanding were far more mixed. Several students, for example, were unsure about how this project contributed to their development as a teaching librarian at all, with one student commenting "it was less a practical experience and more a paper-writing exercise" and another student noting that this assignment was so focused on research that it was "more likely to develop your skills as... (sic) an education researcher?" rather than helping to develop teaching experience. In addition, one student felt that the parameters of the assignment were too narrow, and that they had felt constrained by having to write about something so specific when they had so much to learn in the field.

For others, however, this project helped them to reorient their writing and to think more in terms of their audience and their emerging identity, or about what might matter to an Instruction Librarian. As one student highlighted, "it 'forced' me (in a good way) to think in a larger 'academic library' framework." Students also found that the experience provided a unique opportunity to think critically about and formulate their own position and opinions on an instruction topic, with one comment mentioning that "this assignment has helped to crystalize my views on IL [Information Literacy]." Others directly linked the worth of this assignment to their future careers, stating that the opportunity to immerse themselves within current resources in the field and to delve deeper into instructional techniques and activities was incredibly valuable. Similarly, students commented that they found the experience of publishing useful, 
both because it demystified academic writing, or "made the idea of publication less daunting" as well as because it enabled them to add a well-regarded item onto their CV.

Reviewer experiences. Reviewers tended to note a number of different ways in which this assignment could contribute to the development of novice teacher librarian identities and voices. Most importantly, and in contrast to student responses, reviewers found that this assignment introduced students to a number of authentic teacher activities, both in terms of "thinking about the questions they'll have when they are actually in the classroom," as one reviewer put it, as well as in terms of the process in which a librarian may need to engage when they are faced with limited reading opportunities at a busy time of year. The ability to "understand a more 'in the trenches' viewpoint rather than [one which is] completely esoteric or scholarly" was also seen as particularly useful for students as they attempt to mediate between theory and practice or school and the workplace. Reviewers further noted that the chance to publish, or to be "held to a high standard by people in the field" is an important step in the development of teacher librarian understanding, not least because this topic is often dreaded; as one reviewer pointed out "so many LIS students, and even new librarians, either express fear of writing and publishing to me, or ask questions that make it clear that no one else has discussed this with them." Lastly, the assignment was seen to facilitate student development by immersing them within common resources of the field, including conversations that are being held within professional literature and social media.

Reviewers also noted that participation in this assignment affected their own development as an Instruction Librarian or researcher. On the one hand, reviewers indicated that their involvement had helped them to develop more of an understanding of the novice viewpoint, as well as to feel more connected to student perspectives. As one reviewer put it, "I found both an outsider's perspective and the insight into how students versus practitioners approach the same topic very useful." On the other hand, reviewers indicated that providing feedback on these papers helped them to think more carefully about their own mentoring position or role within the field, including their ability (and need) to provide "constructive, formative" feedback to newcomers or "critical advice while supporting and encouraging the student's efforts."

\section{Discussion}

Raising a number of interesting themes related to student and reviewer experiences of this assignment, these findings will now be discussed with reference to the divide between novices and experts, tensions in the field, and the ongoing nature of transition.

\section{Divide between Novice and Expert}

Relating to the first research question, one of the most striking themes that emerged from these findings relates to the stark divisions between novices and experts within Instruction Librarians communities. Beyond the obvious differences between the practical experience and knowledge of students and reviewers, comments demonstrate that both groups often have little recall or experience of what it means to be either a newcomer or a more expert person in the field. The recalibration, or adjustment of perspective that many reviewers engaged in after reading student papers, for example, speaks to a lack of prior connection to or engagement with novice points of view. At the same time, the uncertainty that the students expressed at the thought of a "real librarian" reading their paper, as well as their surprise at the breadth of a reviewer's knowledge speaks to students' broader feelings of being disconnected from the instruction communities in which they are trying to participate. Rather than being interpreted as a critique of LIS programs, 
librarians or students though, findings should be seen as demonstrating the importance of fostering the sense of reconciliation and understanding that was reached through participation in this assignment. In serving as an emerging shared object for students, practitioners, reviewers and researchers, this assignment can therefore be seen as forming a site of rapprochement, or as a place where, in collaboratively interpreting, modifying and reconstructing knowledge (Lambert, 2003), new and expert Instruction Librarians learn to value each other's perspective and experience.

\section{Tensions in the Field}

A secondary theme that relates to the first research question refers to the complications or messiness of carrying this assignment out in such a public and open space; participation within social communities should neither be seen as easy, nor as straightforward. On one level, for example, this project can be seen to affirm and corroborate research that speaks to the importance of social engagement in the development of expertise; not only do the experienced individuals in this project validate student activity but they also mediate between theory and practice by repositioning students towards the more tacit values and beliefs of Instruction Librarian groups. On another level, however, these findings illustrate the tensions that can complicate learning in a professional context. As one of the students who participated in this class commented in a later blogpost about the project, Instruction Librarian communities can often be perceived as polarized places "where work is judged and dismissed openly and critically" (Heinbach, Landis \& Hicks, 2016). In addition, the recent and ongoing divisions within some Instruction Librarians communities between defenders of the Information Literacy Competency Standards for Higher Education (ACRL, 1989) and proponents of the replacement Framework for Information Literacy in Higher Education (ACRL, 2015) can only be seen as adding to the already significant graduate school pressures of building a CV and applying for jobs. In some respects, therefore, these findings may demonstrate the limitations of this assignment, which, in exposing students to the power structures that afford and limit community access could risk overwhelming them, or confirming their seeming lack of authority in the field. Yet, as Wenger points out, participating in these communities has the "ability to give rise to an experience of meaningfulness; and, conversely, to hold us hostages to that experience" (1998, $p$. 85). In other words, communities cannot be romanticized, and it is through participating in a sheltered learning opportunity such as this one that student engagement with these uncomfortable tensions and negotiations can be supported.

\section{Ongoing Nature of Transition}

Relating to the second research question, a final theme that emerges from these findings relates to the continuing nature of learning and transition within Instruction Librarians communities. More expressly, these ideas refer to the understanding that learning within professional communities is shared, collective, and most importantly, ongoing. Although the structure of the assignment meant that reviewers were able to provide more specific and targeted feedback to students, comments clearly indicated that both reviewers and students learned from each other in this project, for example, about the existence of new resources. In other words, and while this paper has referred to experts and novices for clarity's sake, these ideas demonstrate that learning can neither be seen as unidirectional, nor as uniquely student centered. Instead, if professional knowledge is produced through the continuous negotiation of meaning then it is clear that learning cannot just be limited to newcomers if this knowledge is to be perpetuated and renewed. 
Findings also point to the interrelated nature of practice, or to the understanding that individual roles and participation changes with time and experience. Several experienced reviewers, for example, pointed out that participation in this assignment helped them to reflect upon their progress as well as the new demands that they face within the field, or how their experience and achievements affects their identity as well as their roles and responsibilities. Highlighting the ongoing nature of transition as well as the dynamism of professional learning, these findings are particularly interesting given that most literature to date has focused upon the individual's initial transition into the workplace rather than upon their ongoing development (for example, see Lloyd, 2007). While acknowledging that more experienced individuals tend to have access to the resources that can mediate these changes, these findings highlight that the development of expertise is both continuous and complex.

\section{Limitations and Recommendations}

These comments, as well as final grades for this paper demonstrate that this assignment was carried out successfully and to a high standard. Nonetheless, it is clear that findings from this study, which are derived from the experiences of one LIS class and a small number of handpicked reviewers, are limited in scope and not generalizable. Most importantly, the class consisted of several different assignments and in-class activities, of which this paper was only one project. Given that assessment did not attempt to differentiate between these activities, and the study does not compare and test the assignment against another version, it is impossible to pinpoint exactly how this project helped students to develop as Instruction Librarians. Notwithstanding, this paper did not set out to establish the "best way" to design instructional opportunities. Instead, this study successfully explores student and reviewer responses to one attempt at designing a writing assignment that structures participation within Instruction Librarian communities.

Responses from students, reviewers and the instructor coincided in suggesting several key changes to future iterations of this assignment. One of the major recommendations refers to topic choice, which several students found challenging due to their inexperience within Instruction Librarian communities. Greater support for topic choice, including being able to brainstorm topics in class or with a student partner rather than just with the instructor, would help future students feel more comfortable in this process. Another recommendation relates to the timing of the external review, with many students indicating that they would have felt more comfortable if their work could have been reviewed by a classmate or by the instructor before being sent to the professional reviewer. While acknowledging that the addition of more revision time would be hard to achieve given the brevity of the semester, future iterations of this assignment will have the external reviewer read the second rather than a first draft of the paper. This will address student concerns about the quality of their work while also facilitating the reviewer's workflow by ensuring that they can focus on the content of the assignment rather than on grammar, writing or format. Lastly, the instructor will work to clarify the scope of the assignment as well as reviewer instructions. Some students struggled with the length of the paper, finding it hard to maintain an informal tone when reviewing scholarly literature. Similarly, a couple of reviewers indicated that they were unsure about what constituted a suitable reading or engagement level for a "busy librarian" in the field. Future assignments will clarify these expectations, as well as reviewing potential templates for the assignment, such as the ACRL's Tips and Trends series (n.d.). 
Lastly, future iterations of this assignment will investigate the effect of projects such as these on reviewer time and workload. This project would have been impossible to carry out without the generous assistance of the 19 reviewers who provided extensive feedback within a very short timeframe and at an extremely busy period of the year. However, although the students valued reviewer comments for their authentic insights into librarian practice, it is clear that reviewing a paper constitutes considerable scholarly labor. This is especially true for public, school or non-tenure track librarian reviewers who may not have the same expectations and allowances for service as academic reviewers often do. While reviewers indicated their willingness to contribute to the training of future librarians, it is important that the labor that is involved in a project like this is both acknowledged and balanced.

\section{Conclusion}

Learning to teach has often been positioned as a purely practical endeavor, or one that is grounded in the mastery of individual and generic skills such as public speaking or assessment techniques. Beyond these practical competencies, however, findings from this study highlight the importance of engaging new Instruction Librarians into the activities and the shared ways of thinking within the professional communities that they wish to join. As Drabinski points out with reference to the Framework for Information Literacy in Higher Education (ACRL, 2015), "to have a position on the framework is to occupy a position in a professional discourse, one where one's knowledge and values, informed by practice, gives one the right to speak" (2016, p.34). Beyond merely giving students a voice within professional communities, however, it is through the active interpretation of understanding that is inherent within this assignment that students can also start to challenge, critique or to develop practices outwards and in "unexpected directions" (Lambert, 2003, p. 234). As Friend and Morris (2013) point out, learners often have a deeper investment in teaching than educators do, and it is important that Instruction Librarian education continues to create opportunities to let these student perspectives and experiences be heard. Most importantly, this paper demonstrates both the importance of exposing students to professional communities and practices within LIS education, as well as providing an example of how LIS educators can use technology to facilitate these connections. While experiential education often emphasizes the need to integrate practical or everyday librarian activities into instruction, the professional communities who will be supporting student learning after graduation are mentioned far less frequently. By demonstrating how increasingly open technologies can be used to facilitate student engagement within these communities, this paper provides a model of engagement that could be adapted by LIS educators within a number of different fields.

\section{References}

Alexander, L., Colman, J., Kahn, M., Peters, A., Watkinson, C., \& Welzenbach, R. (2016). Publishing as Pedagogy: Connecting Library Services and Technology. Educause Review. Retrieved from http://er.educause.edu/articles/2016/1/publishing-as-pedagogy-connectinglibrary-services-and-technology

Association of College and Research Libraries (ACRL). (1999). Information Literacy Competency Standards for Higher Education. Retrieved from: http://www.ala.org/acrl/standards/informationliteracycompetency 
Association of College and Research Libraries (ACRL). (2015). Framework for Information Literacy in Higher Education. Retrieved from http://www.ala.org/acrl/standards/ilframework

Association of College and Research Libraries (ACRL). (n.d.) Instruction Section. Tips and Trends series. Retrieved from:

http://www.ala.org/acrl/aboutacrl/directoryofleadership/sections/is/iswebsite/projpubs/tipsandtre $\underline{\text { nds }}$

Bewick, L., \& Corrall, S. (2010). Developing librarians as teachers: A study of their pedagogical knowledge. Journal of Librarianship and Information Science, 42(2), 97-110. doi:

10.1177/0961000610361419

Botts, C., \& Emmons, M. (2002). Developing teaching competencies for instructors in the academic library: A case study. Public Services Quarterly, 1(3), 65-81. doi:

10.1300/J295v01n03_07

Caprio, M. (2014). Student publishing: Future scholars as change agents. OCLC Systems \& Services: International digital library perspectives, 30(3), 144-157. doi: 10.1108/OCLC-012014-0003

Cooke, N., \& Hensley, M.K. (2013). The critical and continuing role of library and information science curriculum in the teacher training of future librarians. Information Research 18(3). Retrieved from: http://www.informationr.net/ir/18-3/colis/paperS02.html\#.VOqhHBbs6FJ

Cooper, L. Z. (2013). Student reflections on an LIS internship from a service learning perspective supporting multiple learning theories. Journal of Education for Library and Information Science, 54(4), 286-298. Retrieved from

http://files.eric.ed.gov/fulltext/EJ1074140.pdf

Davies-Hoffman, K., Alvarez, B., Costello, M., \& Emerson, D. (2013). Keeping pace with information literacy instruction for the real world: When will MLS programs wake up and smell the LILACs? Communications in Information Literacy, 7(1), 9-23. Retrieved from: http://comminfolit.org/index.php? journal=cil\&page=article\&op=view \&path=v7i1p9\&path=159

Drabinski, E. (2016). Becoming librarians, becoming teachers: Kairos and professional identity/Devenir bibliothécaire, devenir enseignant: Le Kairos et l'identité professionnelle. Canadian Journal of Information and Library Science, 40(1), 27-36. Retrieved from: https://muse.jhu.edu/article/611575

Eckert, P., \& Wenger, E. (1994). From school to work: an apprenticeship in institutional identity. Working Paper, Institute for Research on Learning. Retrieved from https://pdfs.semanticscholar.org/7222/ac9e7aecd4ed7bd2e427cca3a59c4452a4ae.pdf

Friend, C. \& Morris, S.M. (2013). Listening for student voices. Hybrid Pedagogy. Retrieved from http://www.digitalpedagogylab.com/hybridped/listening-for-student-voices/ 
Harris, B. (2008). Communities as necessity in information literacy development: Challenging the standards. Journal of Academic Librarianship, 34(3), 248-255.

doi:10.1016/j.acalib.2008.03.008

Heinbach, C., Landis, C. \& Hicks, A. (2016) Publishing practice: Developing a professional identity. ACRLog. Retrieved from http://acrlog.org/2016/04/26/publishing-practice-developinga-professional-identity/

Hensley, M. K. (2015). Improving LIS education in teaching librarians to teach. In, The Proceedings of the ACRL 2015 Conference, Chicago: ACRL

Hicks, A., \& Howkins, A. (2015). Tipping the iceberg: A collaborative approach to redesigning the undergraduate research assignment in an Antarctic history capstone seminar. The History Teacher, 48(2), 339-370. Retrieved from: http://www.societyforhistoryeducation.org/pdfs/F15_Hicks_and_Howkins.pdf

Inskip, C. (2015). Information literacy in LIS education: Exploring the student view. Journal of Information Literacy, 9(2), 94-110. doi:10.11645/9.2.1977

Ishimura, Y., \& Bartlett, J. C. (2009). Information literacy courses in LIS schools: Emerging perspectives for future education. Education for Information, 27(4), 197-216. doi:10.3233/EFI2009-0883

Konkola, R., Tuomi-Gröhn, T., Lambert, P., \& Ludvigsen, S. (2007). Promoting learning and transfer between school and workplace. Journal of Education and Work, 20(3), 211-228. doi: $10.1080 / 13639080701464483$

Limberg, L., Sundin, O., \& Talja, S. (2013). Three theoretical perspectives on information literacy. Human IT: Journal for Information Technology Studies as a Human Science, 11(2), 93130. Retrieved from: http://www.hb.se/bhs/ith/2-11/llosst.pdf

Lambert, P. (2003). Promoting developmental transfer in vocational teacher education. In, T. Tuomi-Gröhn \& Y. Engeström (Eds), Between school and work: New perspectives on transfer and boundary-crossing (233-254). Amsterdam: Pergamon.

Lave, J., \& Wenger, E. (1991). Situated learning: Legitimate peripheral participation. Cambridge, UK: Cambridge University Press.

Lloyd, A. (2007). Learning to put out the red stuff: Becoming information literate through discursive practice. The Library Quarterly, 77(2), 181-198. doi: 0024-2519/2007/7702-0005

Lloyd, A. (2014). Following the red thread of information in information literacy research: Recovering local knowledge through interview to the double. Library \& Information Science Research, 36(2), 99-105. doi:10.1016/j.lisr.2013.10.006 
Miller, C. (2013). Riding the wave: Open access, digital publishing, and the undergraduate thesis. Opening Keynote for the USETDA 2013 Conference. Retrieved from http://works.bepress.com/char_miller/32/

Moring, C. (2012). Newcomer information practice. Human IT, 11(2), 1-21. Retrieved from http://etjanst.hb.se/bhs/ith/2-11/cm.pdf

Pickard, A. (2007). Research methods in information. London: Facet Publishing.

Rogoff, B. (2003). The cultural nature of human development. Oxford, UK: Oxford University Press.

Saunders, L. (2015). Education for instruction: A review of LIS instruction syllabi. The Reference Librarian, 56(1), 1-21. doi:10.1080/02763877.2014.969392

Selematsela, D. N. S. \& Du Toit, A. S. A. (2006). Competency profile for librarians teaching information literacy. South African Journal of Libraries \& Information Science, 73(2), 119-129. Retrieved from https://www.researchgate.net/profile/Adeline_Du_Toit/publication/260807729_Competency_pro file_for_librarians teaching_information_literacy/links/0046353ce014d13836000000.pdf

Shonrock, D., \& Mulder, C. (1993). Instruction Librarians: Acquiring the proficiencies critical to their work. College \& Research Libraries, 54(2), 137-149. doi:10.5860/crl_54_02_137

Sommers, N., \& Saltz, L. (2004). The novice as expert: Writing the freshman year. College Composition and Communication, 56(1), 124-149. doi:10.2307/4140684

Sproles, C., Johnson, A. M., \& Farison, L. (2008). What the teachers are teaching: How MLIS programs are preparing academic librarians for instructional roles. Journal of Education for Library and Information Science, 49(3), 195-209. Retrieved from http://www.jstor.org/stable/40323773

Stone, G., Jensen, K., \& Beech, M. (2016). Publishing undergraduate research: Linking teaching and research through a dedicated peer-reviewed open access journal. Journal of Scholarly Publishing, 47(2), 147-170. Retrieved from http://eprints.hud.ac.uk/25990/

Tuomi-Gröhn, T. (2003). Developmental transfer as a goal of internship in practical nursing. In, T. Tuomi-Gröhn \& Y. Engeström (Eds), Between school and work: New perspectives on transfer and boundary-crossing (199-231). Amsterdam: Pergamon.

Vygotsky, L. S., (1978). Mind in society: The development of higher psychological processes. Cambridge: Harvard University Press.

Walkington, H. (2012). Developing dialogic learning space: The case of online undergraduate research journals. Journal of Geography in Higher Education, 36(4), 547-562. doi:

10.1080/03098265.2012.692072 
Walkington, H., \& Jenkins, A. (2008). Embedding undergraduate research publication in the student learning experience: Ten suggested strategies. Brookes E-journal of Learning and Teaching, 2(3). Retrieved from:

http://bejlt.brookes.ac.uk/article/embedding_undergraduate_research_publication_in_the_student _lear ning_experi/

Walter, S. (2008). Librarians as teachers: A qualitative inquiry into professional identity. College \& Research Libraries, 69(1), 51-71. doi:10.5860/crl.69.1.51

Wenger, E. (1998). Communities of practice: Learning, meaning, and identity. Cambridge, UK: Cambridge University Press.

Wenger, E. (2010). Communities of practice and social learning systems: the career of a concept. In C. Blackmore, (Ed), Social learning systems and communities of practices (179-198). London: Springer.

Westbrock, T., \& Fabian, S. (2010). Proficiencies for Instruction Librarianss: Is there still a disconnect between professional education and professional responsibilities? College \& Research Libraries, 71(6), 569-590. doi:10.5860/crl-75r1

Westbrook, L. (1999). Passing the halfway mark: LIS curricula incorporating user education courses. Journal of Education for Library and Information Science, 40(2), 92-98. Retrieved from: http://www.jstor.org/stable/40324119 


\section{Appendix A}

\section{Reviewer Survey}

1. What did you think of this writing/publishing assignment?

2. How was the process of reviewing these papers? What major issues did you see? What surprised you?

3. What do you feel are the benefits and the drawbacks of this assignment?

4. Do you think this assignment forms a worthwhile part of a library instruction class? Why or why not?

5. Was this assignment useful to you as a practicing librarian in any way? Why or why not?

6. What suggestions do you have for me if I were to do this assignment again?

7. Any other comments?

\section{Student Survey}

1. Do you think this assignment formed a worthwhile part of this class? Why or why not?

2. Do you think this assignment has or will help you develop as an Instruction Librarians? Why or why not?

3. How was the peer review process? Was it helpful or not?

4. Did you feel worried at any time about this assignment? When and why?

5. What suggestions do you have for Alison if she were to do this assignment again?

6. Any other comments? 